\title{
Identification of Transferable Competencies and their Impact on the Paradigm Change in Higher Education in the 21st Century
}

(D)Lucie Smékalová ${ }^{1}$ Ph Dr., Ph. D et Ph.D.; (D) Jiřina Sněhotová ${ }^{2}$ Mgr.; (1) Barbora Jordánová ${ }^{3}$ Ing. Czech University of Life Sciences Prague, Institute of Education and Communication, Czech Republic smekaloval@ivp.czu.cz'; snehotova@ivp.czu.cz²; jordanova@ivp.czu.cz ${ }^{3}$

\begin{abstract}
The article presents the results of a qualitative research of an Erasmus+ KA201 project "CATCH 21st Skills - Changing the Approach to Teaching in Higher Education". The main method used in the research was a semi-structured interview led with six human resources (HR) managers of six Czech private companies. The aim of the qualitative research was to find answers to the question: Which transferable competencies are the most important for the graduate's successfulness in the labour market? After completing the interviews, the research team was able to link the concrete 21 st century skills with four competence areas (sub-themes), to identify the two most important clusters of competencies (communication and collaboration) which are the most important for the employers. Secondly, the research team members found out what changes in educational paradigm would bring benefits for actual demands of job market. The conclusion of the paper offers ways and tools for development competencies among university students and it brings the description of the thesis for transforming the educational paradigm.
\end{abstract}

Keywords: transferable competencies, qualitative research, HR manager, university graduate, change in the educational paradigm.

\section{Introduction}

The importance of 21 st century skills is not a new concept. The concept is often associated with concrete needs of employers, as competencies have become the global currency of the 21 st century. "The term transferable competencies are not defined unambiguously in the specialized discourse. Transferable competencies are generic capabilities which allow people to succeed in a wide range of different tasks and jobs" (Enterprise in Higher..., 2019, 5). M. Yorke specifies that "the basic idea is that skills learned in one context could fairly readily be transferred to another" (Yorke, 2006, 12). A. Ylonen points out that "transferable skills are important for individuals to enhance their employability, for employers to find qualified and able employees and for the economy that needs highly skilled workforce for economic growth and competitiveness" (Ylonen, 2012, 804). "To become sustainable and competent for functioning in the continuously changing labour market a student has to develop meta-skills and transferable competencies" (Kuijpers, Meijers, 2009).

Setting a diversified goal of education with aims in honing in on students' needs and reflecting a better, more relevant education is something that has evolved throughout history. In the 1980s, a series of reports advocated for educational reform. A "National Prepared: Teachers for 21st Century" (A Nation Prepared..., 1986) was among the first released. Then "Turning Points: Preparing American Youth for the 21st Century" (Turning Points..., 1989) outlined eight principles that valued the needs of youth and aimed to address what is necessary for students to be successful in the coming century.

There are a lot of research studies focused on transferable competences, for example, M. Allen (1993) deals with a conceptual model of transferable personal skills or Czech female scientist J. Vasutova (2001) focuses on the qualification requirements for new roles of teachers. A plenty of surveys were undertaken to analyse transferable competencies, for example - a retrospective survey on degree of saturation of selected transferable competencies of graduates by L. Smekalova and K. Nemejc (2016), theoretical research on knowledge management by J. Davidova and I. Kokina (2018) and research based on the competency-based approach by E. Bogatskaia, S. Savela and L. Yarovaya (2020). The project CATCH 21 research team comes with a new insight to this problematic - in the qualitative research, the members of the team tried to find out which competencies do employers prefer and how they should be developed in higher education?

The aim of the qualitative research was to find answers to the question: Which transferable competencies are the most important for the graduate's successfulness in the labour market? 


\section{Methodology}

The process of qualitative research within the project "CATCH $21^{\text {st }}$ Century Skills" started in December 2019. The main aim of the interviews was to find out what concrete transferable competencies of graduates are the most important for the employer and what training would bring benefits for the actual demands of job market. The research team consisted of four staff (two academics and two researchers) of the Institute of Education and Communication (hereinafter named IEC) of the Czech University of Life Sciences Prague (hereinafter named CZU). A pilot interview was undertaken with a member of HR department of the CZU on $10^{\text {th }}$ December 2019. Only one question was evaluated as unclear - it was item No. 7. The broader text with precise explanation to this question was made after this pilot testing. Two staff from the IEC selected and contacted six HR managers from different Czech or international companies in Prague and set up dates of appointments with them. The interviews were led in January 2020.

The research sample consisted of six managers from six organisations. All organisations are private, five out of them operate in the labour market and one is acting in education, training and youth sector (=private university), four are international companies with corporate management and two of Czech majority in ownership interest. Four companies are leading companies in their sector at the Czech market. Five out of them are situated in capital city of Prague, one out of them is operating in the third biggest city in the Czech Republic - Ostrava. Three of the companies in the Czech research sample are medium sized, three belong to large-sized enterprises. The majority of interviewed people were females and their age were ranked from 28 to 45 years. The length of experience in the HR position in the current company differs, two managers have intermediate working experience and the rest have short experience at the position as an HR manager. More data are presented in Table 1.

Table 1

Statistical data of the research sample

\begin{tabular}{|l|l|l|l|l|l|l|}
\hline $\begin{array}{l}\text { Interviewee's } \\
\text { Data }\end{array}$ & Manager 1 & Manager 2 & Manager 3 & Manager 4 & Manager 5 & Manager 6 \\
\hline Sector & Banking, finance & ICT & Logistic & Marketing & Insurance & Education \\
\hline Operating time & 14 years & 12 years & 3 years & 4 years & 3 years & 2 years \\
\hline $\begin{array}{l}\text { Position in the } \\
\text { firm }\end{array}$ & $\begin{array}{c}\text { Head of Clients' } \\
\text { Service }\end{array}$ & HR Manager & $\begin{array}{l}\text { Recruitment } \\
\text { Specialist }\end{array}$ & HR Manager & $\begin{array}{l}\text { HR } \\
\text { Director }\end{array}$ & HR Manager \\
\hline $\begin{array}{l}\text { Number of } \\
\text { employees }\end{array}$ & 9700 & 180 & 2000 & 40 & 800 & 150 \\
\hline Gender & Male & Female & Female & Female & Female & Female \\
\hline Age & 42 & 40 & 35 & 28 & 45 & 44 \\
\hline Graduate Area & $\begin{array}{c}\text { HR } \\
\text { Management }\end{array}$ & $\begin{array}{c}\text { Economics } \\
\text { and Manag. }\end{array}$ & $\begin{array}{c}\text { Counselling } \\
\text { in Education }\end{array}$ & $\begin{array}{c}\text { HR } \\
\text { Management }\end{array}$ & $\begin{array}{c}\text { Psycho- } \\
\text { social care }\end{array}$ & $\begin{array}{l}\text { Education } \\
\text { of History }\end{array}$ \\
\hline Job Experience & 23 years & 20 years & 17 years & 5 years & 19 years & 18 years \\
\hline
\end{tabular}

\section{Data collection process}

The basement of the interviews was a questionnaire developed by researchers and academic staff from six European universities within the project CATCH $21^{\text {st }}$ Century Skills. This project team divided the $21^{\text {st }}$ century skills into 7 clusters (these clusters are listed later in this article in Table 3). The questionnaire consisted of 19 items. Items 1-7 were short open-ended questions for finding some personal data such a size and sector of company, name of position, length of working experience at the HR position in the company and so on. Further items were open-ended questions, especially extended responses to concrete $21^{\text {st }}$ Century Skills. In the form, there was only one closed scaling question - for giving a value from the scale 1-10 to areas (clusters) of different skills within the item no 17. Data were collected through semi-structured interviews.

There were selected HR managers of the enterprises which employed a larger number of CZU graduates. The researchers also paid attention to selecting HR managers from different industrial sectors. The interviews were organised at the workplaces of questioned HR managers, the average time of each interview took 1,5 hours. Before opening the interview, the questioned HR manager was given a sheet with all seven skill clusters, each cluster was explained in detail and concrete skills were assigned to 
each cluster for clear interpretation. During the interview, three people were present- one HR manager (interviewed person), one interviewer (IEC academic staff) and one recorder (IEC researcher). The recorder took notes during the interview and coded them in the sheet of MS Office Word. Finally, the word document with answers was sent to the questioned HR manager, who had a chance to correct any unclear answers and gave authorization to record.

The data obtained from six interviews were coded into an excel sheet by the IEC researcher. The data analysis process ran from $4^{\text {th }}$ to $16^{\text {th }}$ March 2020 . For this purpose, content analysis method was used to enable an objective and systematic analysis of oral or written data. There were two IEC staff responsible for this task, who found out that all answers were valid - they represented actual situations in the field, and they were evaluated as reliable, objective and applicable. One IEC academic staff completed written reports of findings from the analysis, she inducted and deducted conclusions from them. This process took ten days (from $17^{\text {th }}$ to $27^{\text {th }}$ March 2020).

\section{Results and discussion}

After completing semi-structured interviews with six HR managers, the CATCH 21 project research team was able to define four sub-themes linked to transversal competencies. Moreover, several concrete categories of skills were merged to each sub-theme. Table 2 shows the results of the content analysis clustered into competencies as the main theme, which included the sub-themes: knowledge, skills, personal traits, and vocational identity and its categories

Table 2

Analysis of results related to semi-structured interviews with HR managers

\begin{tabular}{|c|c|c|c|}
\hline Themes & Subthemes & \multicolumn{2}{|c|}{ Categories (obtained from managers) } \\
\hline \multirow{4}{*}{$\begin{array}{l}\text { Compe- } \\
\text { tencies }\end{array}$} & Knowledge & $\begin{array}{l}\text { Knowledge-based related to content area } \\
\text { General knowledge }\end{array}$ & $\begin{array}{l}\text { Knowledge of a specific position } \\
\text { Computer literacy }\end{array}$ \\
\hline & Skills & $\begin{array}{l}\text { Communication and negotiation skills } \\
\text { Building and maintaining relationship skills } \\
\text { Czech language } \\
\text { English language } \\
\text { Other foreign language skills } \\
\text { Collaboration skills }\end{array}$ & $\begin{array}{l}\text { Leadership skills } \\
\text { Customer orientation skills } \\
\text { Problem-solving skills } \\
\text { Learning with technology skills } \\
\text { Self-management skills } \\
\text { Creativity and agility skills } \\
\text { Intercultural skills } \\
\text { Analytical and critical thinking }\end{array}$ \\
\hline & $\begin{array}{l}\text { Personality } \\
\text { Traits }\end{array}$ & $\begin{array}{l}\text { Confident / Flexible } \\
\text { Adaptive to change } \\
\text { Responsible / Autonomous } \\
\text { Fair-minded / Integrated } \\
\text { Entrepreneur }\end{array}$ & $\begin{array}{l}\text { Assertive / Polite } \\
\text { Stress resistant } \\
\text { Empathetic / Sociable } \\
\text { Disciplined / Mature } \\
\text { Proactive }\end{array}$ \\
\hline & $\begin{array}{l}\text { Vocational } \\
\text { Identity }\end{array}$ & $\begin{array}{l}\text { Motivation (eagerness) } \\
\text { Quality management (right at the first time) } \\
\text { Goal Orientation } \\
\text { Vocational self-development }\end{array}$ & $\begin{array}{l}\text { Adaptation to corporate culture } \\
\text { Versatility } \\
\text { Complexity } \\
\text { Growth mind-set }\end{array}$ \\
\hline
\end{tabular}

\section{Knowledge}

"Knowledge is considered by many professionals to be a prerequisite for work success. However, more than a field of education or a university degree in an expected major, the managers consider as the most important the knowledge associated with a particular position that cannot be obtained by classical institutional education. They also emphasize continuing vocational training related to a job position (Duru et al., 2020)".

The importance of the knowledge related to a particular position can be summarized by a statement of interviewed HR managers of the ICT company: "In our company we have created a competency model (a package of competencies), which are important across all positions. General ones across positions are, for example, ICT, language and communication skills. For each position, we have a value assigned 
to each competency on a scale of 1-6, which defines what each person should do in a particular position... It is necessary to define all competencies, the selection process is defined in a better way, but the assigned value from the scale at the job interview is then usually shifted higher during the work activity due to training and the length of practice to a particular position."

Another HR manager in the field of online marketing explained that: "One thing is the seniority of the people we need - we seek for candidates with sufficient experience in similar projects and knowledge of online marketing in a comprehensive perspective. There are not many candidates with a long experience in online marketing because the field is new in the Czech Republic."

Beside specific knowledge related to a particular position, some experts also point out the importance of general overview knowledge and general computer literacy. HR manager of IT company mentioned the attitude of the millennials to general knowledge: "Although we are currently recruiting a lot of skilful people, I must say that people born before 2000 are more skilful and have a better "goal orientation". The millennials think they would achieve many goals with no effort, they lack active approach and autonomy, academic staff make them feel elitist for the future in IT, but they have no general overview."

\section{Skills}

All managers in the research sample consider "Communication" and "Collaboration" (especially interpersonal skills) necessary for almost all professional positions to better work within interdisciplinary teams and to solve various and versatile work demands. This is also related to a good command of the Czech and English language and other foreign language skills. The manager of customer service in the biggest Czech bank emphasized the importance of communication skills: "For the position of specialists of the Call Centre, we seek for candidates with excellent communication in Czech and English language, especially negotiation and active listening skills and empathy are crucial. In this world, there are many university' graduated candidates, who are able to produce excellent monologues (presentation) but they are really low in a dialogue. They lack interaction skills."

One manager answered to question what they are missing the most when hiring candidates: "I would say communication and cooperation skills are the most crucial. However, of course, it depends on what position we organise the recruitment for. People are used to act individually, especially the millennials. They do not want to bear the consequences of their decisions, taking responsibility for their own decision is problematic for them."

Another questioned manager shares this opinion: "When dealing with junior staff it is necessary to train them how to operate in an environment of freedom and responsibility - they need to be trained in time management, self-management and self-development, so the self-direction cluster is the most important for us. Newly hired employees usually learn it during work. It is related to the growth mind-set, if the staff enjoys the job, she can be successful and work well.

Another one explained: "I cannot tell that there would be one concrete characteristic or competence which we would miss among almost all candidates. Maybe I miss, especially among staff under 35 years old, stress resistant persons for both positions (specialist and supervisors) most often, and I also miss the art of dealing with people in a polite way and empathy among young supervisors. Therefore again, we are going back to the communication and collaboration skills."

Manager shared similar views in a marketing company, she briefly summarized the lack of skills with the statement: "It is not easy to find candidates with skills of independence, proactivity and taking responsibility for own work (not expecting someone to lead me).

Another HR manager explained how the package of transferable competencies are essential nowadays to be successful at work: "Current life is bringing new demands on people and employees, everything is faster, there is too much stress around us. Nowadays there is an IT and knowledge society, information sharing is the most important for all of us. The young staff prefers to work from home and the workfree-time balance is very important for them.

Another interviewed Czech HR manager listed examples of self-direction skills: "Skills that allow a person to be successful at this time, the ability to learn new things, critical thinking, to learn to recognize what is right and objective." 
Overall "Ability to learn" is considered more important than actual knowledge for most of the managers when hiring candidates for the majority of positions. "Alpha and omega for us is the ability to learn, we do not need passive employees. Suitable method to identify such characteristics among candidates is a behavioural interview, especially the question whether he/she did school projects works very well."

Finally, the managers have to be able to work with people to lead and motivate them in an appropriate way: "For the position of supervisor of the Call Centre, we organise assessment centres to select appropriate candidates. We really need people who are able to lead a team, people disposed with natural authority but also empathy, managers who are able to delegate activities and duties to their team members and who dispose with a know-how how to motivate people and inspire others."

\section{Personality Traits and Vocational Identity}

The HR managers consider personal traits of graduates to be essential in business life. Behaviour, acting, feeling and thought patterns are equally important as skills. Some personality traits have become crucial, but it differs in association with their company environment. The working environment of a goal-oriented corporate company is different from the work atmosphere in an ICT or a marketing firm. All managers in the Czech research sample used a behavioural interviews to find out personal characteristics of the graduates. This proves answer of the HR manager of logistic corporate company: "Depending on the position, the recruiting process includes either a personal interview or attending AC especially in terms of manager position. During the job interview, we use the STAR (situation-task-action-result) method, e.g., question: Can you describe the situation in which you had to decide quickly?"

The same manager also explained that her company top management works much more with "an attitude" than "competency clusters": "We have four pillars - work-speed, passion and can-do-attitude, right at the first time in our company vision. We are still looking for a customer-focused team player because we are a corporate company and our manager has to communicate with a large number of clients."

Personality traits and vocational identity may differ company by company; however, managers usually expect the following critical and self-direction characteristics summarized by one of the interviewed managers: "We need people who are very adaptable, flexible, versatile (the company is growing very fast, the nature of the projects, their size and clients are always changing), our staff have to dispose with internal focus of control, self-management, own engine... Our managers have to be able to solve problems quickly, to share know-how help and give advice. Individualists will not last for a long time in our company. A lot of business-oriented people have to think not only about the job, but also about the impact of work on the clients."

\section{The results of descriptive analysis}

One of the questionnaire items was a closed scaling question, in which the participants rated from 1 to 10 the importance of seven chosen competencies. Table 5 shows the HR managers' ratings of $21 \mathrm{st}$ century skills. The interviewed managers consider the two skills of newly hired managerial staff as the most important - "Collaboration" and "Communication".

Table 3

Managers' ratings of 21 st century skills in terms of their importance for recruitment

\begin{tabular}{|c|c|c|c|c|c|c|c|c|c|}
\hline List of $21^{\text {st }}$ Century Skills & 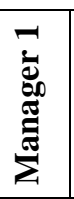 & 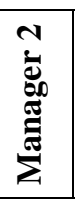 & 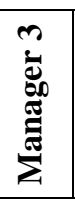 & 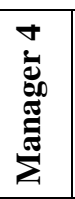 & 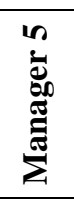 & 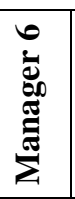 & 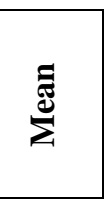 & 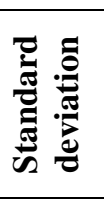 & 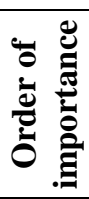 \\
\hline Critical Thinking & 9 & 10 & 9 & 9 & 8 & 8 & 8.83 & 0.687 & 3 \\
\hline Collaboration & 10 & 10 & 10 & 10 & 10 & 10 & 10.00 & 0.000 & 1 \\
\hline Communication & 10 & 10 & 9 & 8 & 10 & 10 & 9.50 & 0.764 & 2 \\
\hline Creativity \& Innovation & 9 & 5 & 5 & 10 & 7 & 8 & 7.33 & 1.886 & 6 \\
\hline Self-Direction & 8 & 9 & 7 & 10 & 9 & 9 & 8.67 & 0.943 & 4 \\
\hline Making Global and Local Connections & 9 & 8 & 8 & 5 & 8 & 4 & 7.00 & 1.826 & 7 \\
\hline Using Technology as a Tool for Learning & 7 & 9 & 10 & 9 & 7 & 5 & 7.83 & 1.675 & 5 \\
\hline
\end{tabular}


The "Collaboration" achieved the highest mean score (10 out of 10) in the research. All Czech questioned HR managers from different sectors viewed that collaboration is completely crucial when recruiting an employee because of heterogeneous work-teams, the employees have to be able to work together on a common task. HR managers use behavioural or competency-based interviews to diagnose such competencies in candidates' CV, but also conduct interviews with their ex-work superiors who are listed in the references in the CV. For the critical and leading positions, they also apply assessment centres and psychological tests.

"Collaboration" means for corporate companies an absolute crucial skill because of the necessity to work with different types of people across the company to know who to ask for advice or consultation, it summarises one interviewed manager. "All the results are presented as results of the whole team, and on the other hand all the team members are responsible for a failure."

Even in consulting company, the HR manager confirmed collaboration as the key competence because none project is done by one person. "We must engage different positions of different specializations, because there is a demand for a lot of knowledge that one person does not have and thus, we need to work together".

Another questioned HR manager confirmed this by this statement: "The organization structure is flat. All team members communicate and cooperate with each other. As in any business, it may happen that interests are different, and collaboration is essential to us". Another manager explained: "Collaboration is the most important skill, the Czech Republic is too small country, there are not so many opportunities, the Czechs are full of rivalry, they are afraid of sharing own portfolio on knowhow. However, keeping own know-how of some employees is a really big thread for the company."

"Communication" skills are really connected with collaboration competencies and represent other essential skills that questioned Czech HR managers rated with 9,5 out of 10. All managers consider this skill very important. Interpersonal skills such as communication and collaboration are necessary for good functioning of teams, departments and all company. According to one manager "working with people always need skills such as empathy, interactivity, good listening skills and negotiation skills". "Communication" is usually one of the categories of competence model and it is important for sharing information and ideas. One manager stated the importance of communication: "Being able to express ideas quickly, to perceive others accurately and give feedback is essential for us. Each manager undergoes communication training and then trains his/her team members. There are face-to-face evaluation meetings where the supervisor discovers the expectations and problems of the subordinates. The team leader evaluates together with the subordinate what s/he has done wrong, he/she makes communication analysis."

Thus, "Communication" is important for all roles and positions for achieving agreements within a team, for preventing conflict, for being able to enforce concrete idea and present a project goals and results. According to one manager, communication is especially important for those "that are in contact with clients, those supervisors have to dispose with perfect presentation skills, ability to explain the idea and strategy and ability to communicate continuously when the client knows nothing. Communication is a significant tool for building relationships with a client or a partner institution."

One manager also expressed that personal communication is more important than written one with the following statement: "It is nice that we do not handle everything by e-mails, but in personal contact. We have been growing a lot, so we need to communicate well." One manager stated: "I do not like to categorize the 21 st skills into separate categories, I think that they are linked to each other, they overlap together, strong blending is, for example, between communication and collaboration. In the knowledge society, the ability of effective information exchange is much more important."

"Critical Thinking" and "Self-Direction" are considered as other important skills as well related to nowadays demands to make quick and high-quality decisions and orientate in the amount of information, effectively manage own work, time, stress, motivation and, last but not least, self-education. The respondents clearly showed different views on the following skills: "Using Technology as a Tool for Learning", "Creativity and Innovation" and "Making Global and Local Connections". Those skills are required for some of the positions and/or in some businesses, however other managers pay less attention to those abilities while recruiting. 
After all, the most positive finding of the research is that the HR managers perceive candidates quite well prepared with general knowledge and some skills. However, Czech HR managers feel the biggest lack of self-direction skills to better handle freedom, autonomy and responsibility.

Two interviewed HR managers recommended that universities should be more closely connected with practice in private companies from the beginning of their studies. One of the HR managers stated: "I recommend that students should take longer internships in companies than acquiring soft skills in concretes subjects at the secondary school or university. We recommend choosing more practically based topics of bachelor or master theses. The problem is that companies do not want to share and spend time with a student and train him/her during practice. It works at colleges that are found by a particular company for their need to attract many specialists in the field, such as Unicorn College or Skoda Car Company."

Nevertheless, two other managers expressed that they can teach new employees to most of the knowledge related to the positions and expertise, but they are missing mostly transferable competencies. One of them mentioned: "What a candidate does not get in the family, it is so hard to catch up later". According to the other manager they are able to teach new candidates all knowledge if they feel motivated and are willing to learn. However, the most important is great fit into company culture. This opinion represents saying of the manager of the Czech biggest bank: "The role of university which produces graduates - our employees is essential. Offering some extra courses can bring benefits to their soft skills but I think the school environment is more important than the methodology. If the school offers a creative, a cooperative and pleasant environment, the students are happy at school and they are more open minded to be innovative, creative and so on. If the academic staff encourage them to work in team, they share information and views, so later they will be great employees, they will not hide information, they will share their own tips, ideas, experience and guidelines with other staff, they will be team players. The university environment is alpha and omega of success and popularity of staff!"

\section{Recommendation}

Regarding the transformation of educational paradigm, all questioned HR managers share the opinion that there is not necessary to implement new curriculum to achieve the better preparedness of university students for the job market. All of them recommended using didactic methods in appropriate lessons to train students' soft skills more often than in previous academic years. During the seminars, workshops or trainings at higher education institutions students take part in practical exercises with the help of a variety teaching methods to develop their competencies. As a good example can be problem solving methods such as heuristic interview or six thinking huts by E. de Bono (1985), role-play methods by J.L. Moreno (1942), synectics (creative method) or cooperative learning or project education.

T. Sinkus speaks about a variety of methods used in teaching English language at the Latvia University of Life Sciences and Technologies, which help students to strengthen their collaboration skills and critical and creative thinking: "To achieve better results in collaborative problem solving students should develop social skills, flexibility and empathy, an ability to compromise, work respectfully with others to make decisions considering the needs of the whole group and considering the views of all group members, an ability to accept different roles, and share responsibility for the created common product" (Sinkus, 2020, 144). "The teacher formed small groups of 4-5 people to avoid student non-participation. By assessing students both individually and as a group the teacher ensured individual accountability of the group members. Moreover, the students had to evaluate their own participation as well as that of their peers. Assigning meaningful roles such as a manager, monitor or leader for each case-based task gave students ownership of the case study process and allowed the teacher to assess students based on accomplishing of these roles" (Sinkus, 2020, 146).

Finally, the interviewed HR managers concluded that the better collaboration between universities and private business companies will be a way of strengthening the transferable competencies of students during their study. They emphasised great advantage if students would link their diploma thesis research with a process and situation at some existing company.

There is also important to add that "the continuous process of development of knowledge, intellectual abilities, competencies and practical skills, for example, through informal individual activities 
(retraining courses) or informally in the form of self-education from everyday activities (activities at work, leisure time, and so on) cannot be neglected (Nemejc, Smekalova, Kriz, 2019, 103)."

\section{Conclusions}

After conducting six semi-structured interviews, the research team was able to divide soft skills into four sub-themes of the competencies - "Knowledge", "Skills", "Personality Traits" and "Vocational Identity". By implementation of the qualitative research at selected HR offices in private companies in the Czech Republic it was possible to map that "Collaboration" and "Communication" are completely crucial competencies in nowadays job market. Without them, none of the companies can perform well. The active listening skills, negotiation, capability of dialogue and empathy were mentioned as examples of communication skills most often. Collaboration competencies such as information sharing, ability to guide others, self-drive, politeness are the characteristics which HR managers lack when dealing with supervisors born after millennia. They also mentioned that time management and stress management skills, ability to learn new things, multicultural skills (because of globalization), critical thinking skills (especially being able to identify wrong opinions in the team of fake news in mass media), team-work skills, flexibility and IT skills are really crucial to be successful managers in the turbulent time of our society."

Universities can strengthen transferable competencies through implementation of needed methods into the curriculum or directly into the educational process. Implementation of the curriculum requires analysis of the study plan in relation to the study programme. According to the field of study programme, specific subjects can be applied, for example: Learning Strategies, Activation Methods, Communication and Presentation Skills, Personal Branding, Project Management or cross-curricular activities such as foreign excursions, adaptation course and outdoor training. Another curricular reinforcement is to update the syllabuses of related subjects by including specific actual topics, e.g., time management or stress management. Implementation directly into the educational process means that teachers will use a battery of activation methods that strengthen independent, critical or creative thinking of the students, gamification, if they create specific worksheets for the seminars, or if they offer actual topics for diploma thesis. Academic staff are also advised to use of a variety of forms of e-learning, e.g., flipped classroom, m-learning with micro-learning applications in existing subjects according to the field of interest.

As a reaction to these recommendations six European universities, which are the partners of the abovementioned Erasmus+ project, are working on implementing a new one-semester course titled " 21 st Century Skills". This course will help the university students to strengthen all transferable competencies included in the seven clusters (Table 3 ) and skills within the four mentioned sub-themes of competencies (Table 1). The curriculum of this new course and its verification during the spring semester 2020/21 can be a suitable topic for an article for the next REEP conference.

Finally, the HR managers and the members of the research team concluded that they see a large chance for strengthening soft skills among university students thanks to actual priority topics such as sustainability, development of transferable competencies and innovations sharing in new calls for educational EU projects within the new programme horizon 2021-2027.

\section{Bibliography}

1. A Nation Prepared: Teachers for the 21st Century: the Report of the Task Force on Teaching as a Profession. (1986). Washington, DC: Carnegie Forum on Education

2. Allen M. (1993). A Conceptual Model of Transferable Personal Skills. Sheffield: Employment Department, 128.

3. Bogatskaia E., Savela S., Yarovaya L. (2020). Fostering Responsibility and Teamwork Ability as Professionally Important Transferable Skills among Students at Higher Educational Institutions. In L Gómez Chova, A. López Martínez, I. Candel Torres (Eds.), The Proceedings of International Conference Technology, Education and Development Conference (INTED2020), 14, Valencia: IATED Academy, 209-213. doi: 10.21125/inted.2020.0102

4. Bono de E. (1985). Six Thinking Hats. London: Penquin.

5. Davidova J., Kokina I. (2018). Paradigms, Approaches and Principals of Knowledge Management. In V. Dislere (Ed.), The Proceedings of the International Scientific Conference Rural Environment. 
Education. Personality (REEP), 11. Jelgava: Latvia University of Life Sciences and Technologies, 58-65. doi: 10.22616/REEP.2018.006

6. Duru E., Paksu A.D., Balkis M., Duru S., Bakay M.E. (2020). Examination of 21st Century Competencies and Skills of Graduates from the Perspective of Sector Representatives and Academicians. In Journal of Qualitative Research in Education, 8(4), 1059-1079. Ankara: ANI Publishing. doi: 10.14689/issn.2148-2624.8c.4s.1m

7. Enterprise in Higher Education: Key Features of Enterprise in Higher Education Proposals. (2019). Training Agency. Sheffield: Training Agency.

8. Kuijpers M., Meijers F. (2009). Studieloopbaanbegeleiding in het hbo: mogelijkheden en grenzen [Study career counseling in higher professional education: possibilities and limits]. Den Haag: Haagse Hogeschool, 45. (in Dutch)

9. Moreno J.L., Toeman Z. (1942). The Group Approach in Psychodrama. Sociometry, 5(2), 191-195. doi: $10.2307 / 2785432$

10. Nemejc K., Smekalova L., Kriz E. (2019). A Reflection of the Quality of Education in the Use of Teaching Aids and the Importance of Lifelong Learning. In V. Dislere (Ed.), The Proceedings of the International Scientific Conference Rural Environment. Education. Personality (REEP), 12. Jelgava: Latvia University of Life Sciences and Technologies, 94-103. doi: 10.22616/REEP.2019.012

11. Sinkus T. (2020). Development of Transversal Competences in Case Study-based Professional English Course in Business Administration Studies. In V. Dislere (Ed.), The Proceedings of the International Scientific Conference Rural Environment. Education. Personality (REEP), 13. Jelgava: Latvia University of Life Sciences and Technologies, 142-149. doi: 10.22616/REEP.2020.017

12. Smekalova L., Nemejc K. (2016). Transferable Competencies of Graduates of Vocational Education: a Retrospective Survey 2007-2014. In V. Dislere (Ed.), The Proceedings of the International Scientific Conference Rural Environment. Education. Personality (REEP), 9. Jelgava: LLU, 94-103. Retrieved from https://llufb.llu.lv/conference/REEP/2016/Latvia-UnivAgricult-REEP-2016proceed2255-808X-106-113.pdf

13. Turning Points: Preparing American Youth for the 21 st Century: the Report of the Task Force on Education of Young Adolescents. (1989). Carnegie Corporation of New York. Retrieved from https://www.carnegie.org/publications/turning-points-preparing-american-youth-for-the-21st-century/

14. Vasutova J. (2001). Qualification Requirements for New Roles of Teachers. Prague: Charles University in Prague.

15. Ylonen A. (2012). Student Ambassador Experience in Higher Education: Skills and Competencies for the Future? In British Educational Research Journal, 38(5), 801-811. doi: 10.1080/01411926.2011.583636

16. Yorke M. (2006). Employability in Higher Education: What it is - What it is not. York: The Higher Education Academy, 22. 